DOI: 10.20472/IAC.2019.050.012

\author{
VLADIMIR GRACHEV \\ Lomonosov Moscow State University, Russian Federation
}

NATALIA KURYSHEVA

Burnasyan Federal Medical Biophysical Center, Moscow, Russian Federation

\title{
ENERGY SOURCES, ENVIRONMENT AND PUBLIC HEALTH
}

\begin{abstract}
:
The paper discusses the issue of the impact of various energy technologies on public health since the matter is pressing due to the emergence of new ways to harness energy such as waste incineration. The study shows that coal energy, waste incineration, and transport emissions are major hazards to public health. The study reveals nuclear energy is the most environmentally efficient and has the least adverse impact on public health. The paper demonstrates that the use of waste to generate energy is extremely dangerous for public health and can cause emission of polychlorinated dibenzodioxins, which poses a serious hazard. The paper postulates it is uncertain whether waste incineration is beneficial in terms of energy, but it is dangerous for sure. According to the paper, the use of conventional motor fuels is also hazardous due to benzopyrene emissions. Therefore, it is better to use the energy harnessed at nuclear or gas power plants to fir motor vehicles.
\end{abstract}

\section{Keywords:}

public health, natural gas, polychlorinated dibenzodioxins, nuclear, municipal solid waste, air pollution, benzopyrene

JEL Classification: Q42, Q53, 100 


\section{Introduction and background}

Public health depends largely on the quality of air people breathe. Worldwide, 9 out of 10 people live in places where air quality does not meet the safety requirements set by the World Health Organization. The WHO states in its report (COP24, 2018) that the quality of the air we breathe is deteriorating. Between 2008 and 2013, the global level of air pollution increased by $8 \%$ in all cities where it was monitored. It has been estimated, $6.5 \mathrm{mn}$ deaths per year are caused by lung cancer, chronic obstructive pulmonary disease (COPD), stroke, and other cardiac and pulmonary diseases linked to air pollution.

Both global and local environmental problems affect public health through adverse environmental conditions such as air pollution, which dramatically reduces life expectancy (Wenn and $\mathrm{Gu}, 2012$ ). In some regions located in the vicinity of air pollution sources (i.e. industrial sites), researchers have noticed a higher incidence of cancer (Patra and Andrew, 2015), which is aggravated by vehicle exhaust air (James et al., 2015.). Therefore, complex pollution is extremely dangerous (van der Zee et al., 2016; Leon, 2016).

\section{Results and discussion}

The amount and composition of emissions from energy technologies depend on the amount and composition of the substance used to generate energy.

\section{Coal}

Atmospheric emissions from coal-fired power plants cause so-called acid rains that destroy vegetation, soil, water bodies and, above all, human health. In order to estimate the volume of precipitating acid rain, one can imagine that a thermal power plant (TPP) with a capacity of $1,000 \mathrm{MW}$ and operating on coal with a sulfur content of about $3.5 \%$, releases about 140,000 tonnes of sulfur dioxide per year into the atmosphere despite the use of cleaning facilities, from which about 280,000 tonnes of sulfuric acid are produced. The wind raises the ash from ash dump surfaces and forms dust storms; the annual ash-and-slag wastes volume of the TPP of the CIS currently exceeds 120 million tonnes.

In the process of coal combustion, radioactive contamination of the environment occurs; the radionuclides contained in the coal (238U, 210Pb, 40K, 210Po, 226Ra, 228Ra, 230Th, etc.) are emitted into the atmosphere and concentrated in the ashes. The release of radioactive substances per unit of energy received at a coal-fired TPPs is more than at an NPP of the same capacity. This fact is ignored for some reason in nuclear energy criticism.

\section{Nuclear power}

Nuclear power industry does not consume oxygen, it does not emit harmful chemicals into the atmosphere and water reservoirs, and it reduces the consumption of fossil fuels, the reserves of which are rather limited. In particular, in the five most developed countries of the world, nuclear energy allows to save up to $440 \mathrm{mn}$ tonnes of coal per year $(65.3 \mathrm{mn}$ tonnes in Russia), 350 million tons of oil (40.3 mn tonnes in Russia), up to 280 billion m3 of gas (6.8 bn $\mathrm{m} 3$ in Russia), to prevent the burning of more than $450 \mathrm{mn}$ tonnes of oxygen (36 mn tonnes in Russia), and a land measuring 70 thousand hectares (11 thousand hectares in Russia).

It should be noted that there were no new cases of radiation-related diseases, such as acute and chronic radiation sickness, local radiation injuries registered over the last 10 years. Over the years there are also no cases the discharges and releases of radioactive substances from nuclear facilities into the external environment exceeding standards. There are fewer cases of professional pathologies in the cities where ROSATOM's facilities are located than in Russia as a whole, although medical check-ups are conducted more often in such cities.

Thus, the fear of nuclear energy is unfounded. People used to be afraid of thunder, for example; in other words, the unknown frightens. This is connected to the notion of risk. 


\section{Transport}

It is not a secret that transport is one of the root causes of air pollution in cities. In Russia, the level of air pollution has long been quite high, with motor transport contributing between $80 \%$ and $90 \%$ of the whole volume of pollutants. Figure 1 below shows the dynamics of pollutant emissions by motor transport in Russia.

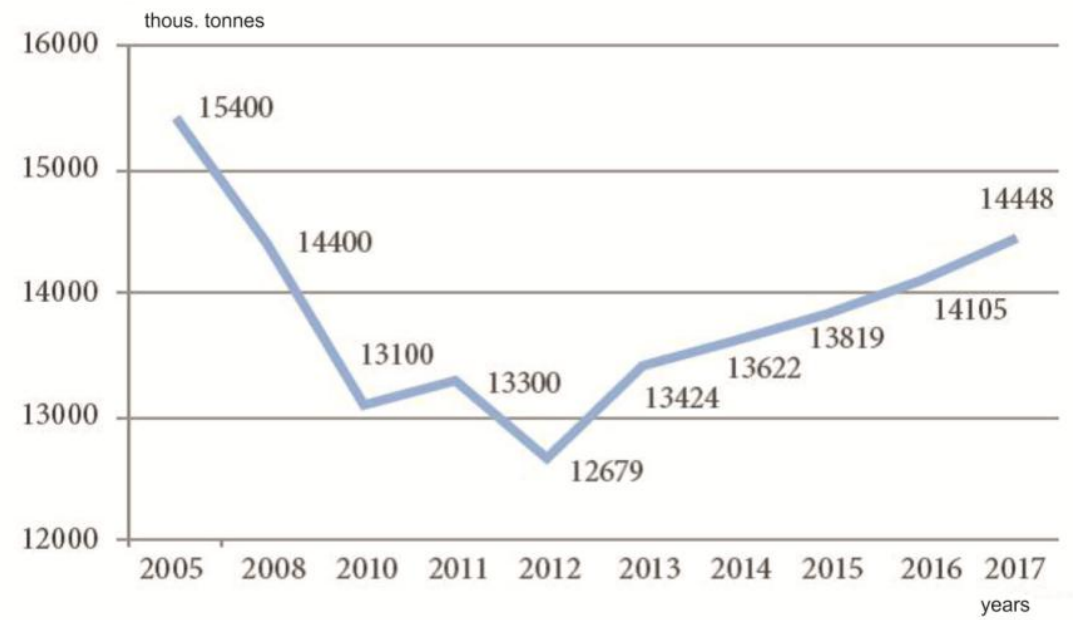

Figure 1: Growth dynamics of pollutants emission by vehicles

According to data of the Governmental Report on State and Protection of the Environment prepared by the Ministry of Natural Resources and Environment of the Russian Federation (2017), the volume of transport emissions has been skyrocketing recently due to the growth of the number of vehicles, which aggravates the situation.

Emissions affect human health, including embryonic development, and lead to diseases of the pulmonary, cardiac, and nervous system. The most common diseases caused by air pollution include acute and chronic bronchitis, infectious lung diseases, pulmonary tract tumours, cardiac diseases, stroke, and infarction. People who live in the vicinity of major highways are at risk, especially if the air around highways is prone to stagnation and heat inversion. All the so-called primary air pollutants (such as $\mathrm{SO} 2, \mathrm{NOX}, \mathrm{O} 3, \mathrm{CO} 2, \mathrm{~Pb}$, and particulate matter) stimulate airway hyper-responsiveness. Moreover, particulate matter can cause a local and systemic inflammatory reaction, which explains their impact on both respiratory and cardiovascular systems. Particulate matter in air results from burning of fossil fuels (especially of diesel fuel). Fine suspended particles (PM2.5) provoke a more intense inflammation than bigger particles do. Present data indicate that air pollution leads to an increase in death rate from all causes, particularly from cardiovascular and pulmonary diseases. Long-term exposure to polluted air enlarges the number of respiratory infections and symptoms among the overall population and can provoke respiratory failure in children.

Among various pollutants, benzopyrene $\mathrm{C} 20 \mathrm{H} 12(\mathrm{BaP})$ is extremely toxic.

$\mathrm{BaP}$ is a carbon-based organic compound that belongs to polycyclic aromatic hydrocarbons. This means it has benzene rings in its structure; and its molar mass is $252.316 \mathrm{~g} / \mathrm{mol}$. There are two isomeric species of $\mathrm{BaP}$. The first $\mathrm{BaP}$ isomer is 3,4-benzpyrene (also known as 1,2benzpyrene), it is a highly toxic carcinogen that can be found in oil, coal, tar, and their combustion products. Moreover, it dissolves easily in oils and human blood serum.

According to Health Standards 2.1.6.695-98, 2.1.6.1338-03, and 2.1.7.2041-06, daily average maximum permissible benzpyrene amount in air and soil is $0.1 \mu \mathrm{g} / 100 \mathrm{~m}^{3}$ (which is equal to $10-9 \mathrm{~g} / \mathrm{m}^{3}$ ) and $0.02 \mu \mathrm{g} / \mathrm{kg}$ in total with an account of ambient level, respectively. In workplace air, daily average maximum permissible benzpyrene amount must be less than $0.00015 \mu \mathrm{g} / \mathrm{m}^{3}$ (as per items 1 and 2 of Health Standard 2.2.5.1313-03). 
Benzpyrene is a first hazard class substance, which means its damaging impact on the environment is extremely intensive and changes it brings about are irreversible and cannot be undone. Benzpyrene is also one of the most powerful and widespread carcinogens. Due to its chemical and thermal stability as well as due to its bioaccumulation and dissolution properties, benzpyrene has mutagenic, embryotoxic, and haematotoxic impact on living beings, as it is stated at nekurim.ru. According to Gao D. et al. (2017) and Rozanova E. et al. (2009), benzpyrene is extremely harmful to human health. Their findings are supported by Gupta P.D. et al. (2018) and PHE Toxicological Review (2018).

However, there is a way to solve or, at least, to alleviate this problem. We can make our cars run on gas, not petroleum products; and therefore, there would be much less harmful emissions in the air we breathe.

\section{Natural gas}

Assessing different types of motor fuel, one should account for emissions not only resulting from vehicle operation but also generated during the whole life cycle, including oil and gas extraction as well as petrol and diesel production; therefore, integrated analysis is employed to assess a fuel type. A means of such an analysis is toxic footprint representing the total pollutant emission volume in the course of the whole production chain and considering their toxicity. A toxic footprint is an indicator of human impact on ecosystems and population health and allows for conduction a comparative evaluation of environmental advantages that different fuels have. The evaluation shows that natural gas from 3 to 5 times environmentally friendlier than diesel and petrol fuels. Governments of various Russian cities strive to switch from petrol and diesel-run public transportation means to those that use gas; this can lead to a drastic reduction of emissions volume, for example, such a step could help reduce emissions and negative impact on health in Moscow and Saint Petersburg by half.

Special attention should be paid to methane-based adsorbent use. The sorbent enables storage of the same natural gas amount as a gas cylinder (250 atm) under much lower pressure (7-10 atm), which induces energy effectiveness and material intensity of infrastructure use. Sorbent storage of motor fuel has an enormous capacity for motor transport with the exception of explosive and fire hazards that are associated with its use.

The set of measures (including the Euro- 5 standard controlling the concentration of harmful substances in exhaust gases) implemented to increase the quality of air as well as the promotion of natural gas motor fuel allowed to cut the number of towns and cities with pollutants going beyond critical concentrations almost by half between 2012 and 2017 (from $1.37 \%$ in 2012 to $0.7 \%$ in 2017). This has allowed for reducing the number of cases of air pollution-related deaths and morbidity by $23.4 \%$ and $5.2 \%$, respectively. However, a full recovery from the consequences of the use of petroleum-based fuels can only be achieved by a large-scale conversion to compressed natural gas-fired transport. Some people believe the problem can be solved by the introduction of electric cars, but this is a blind alley because the use of electric cars will definitely lead to more air pollutants due to a higher burden on power plants that produce electricity by burning fossil fuels. Therefore, natural gas-and hydrogen in the future-is the key.

On the other hand, if transport used the energy generated by a nuclear, solar, or a wind power plant, the problem would solve by itself. Therefore, different combinations of nuclear, solar, wind, and gas energy can be a feasible solution.

\section{Municipal solid waste}

I would also like to add that there are new possible energy sources, for example, the incineration of municipal solid waste (MSW).

Wastes and associated pollution of our planet have become an urgent and global environmental problem which is dangerous for human health and natural environment. 
Storage of MSW at landfills and its discharge into water bodies disturb natural balance and can affect human health, even in small amounts. The harm to human health comes from various MSW-related sources:

- The infiltration of ground- and surface-water by toxic substances. They reach groundwater with rain, and then they go up with groundwater to surface water bodies, where people take water for households and drinking from, which can lead to poisoning and infection contamination.

- The pollution of soil with hazardous substances accumulating in it, which makes it unsuitable for cultivation. Moreover, MSW slowly decomposes and poisons the soil with pathogenic bacterial flora.

- The aggravation of sanitary state in the region and uncontrolled growth of the population of pathogenic agents. Moreover, animals living at a landfill (dogs, birds, ad rodents) also become a source of various infections, such as plague and helminthiasis, which can lead to various epidemics.

- The air pollution origination from landfills can lead to a greater incidence of cancer.

Residents of regions located near MSW landfills can sometimes fill the above-mentioned adverse effects. Landfills are prone to burning, and sometimes residents of such regions have to breathe the air polluted by products of the burning of landfills. The by-products can include such substances as formaldehyde, acetic acid, carbon monoxide, acetaldehyde, and polychlorinated dibenzodioxins that suppress immunity and have a strong mutagenic and cancer-inducing effect.

Furthermore, there is always a lot of furniture at landfills, and the burning of foam rubber used to manufacture furniture pieces releases poisonous nitrile-bearing gases while burning rubber (can be found in tyres) gives off oily dark thick smoke containing hydrogen sulfide and sulphur dioxide. Both gases are hazardous for health. And when organic matter found at landfills decomposes, it produces radon, a dangerous poisonous and radioactive gas that is difficult to detect since it is odourless and colourless.

Polychlorinated dibenzodioxins have recently given rise to growing public concern since are especially dangerous even if released in very small amounts. Therefore, the European Parliament passed a bill on termination of funding of any waste incinerators in March 2019.

In 2011, a waste incineration plant for power generation was built in Harlingen (Netherlands) and pronounced the most technologically advanced in the country. The plant received an air emission permit for $0.01 \mathrm{ng} \mathrm{TEQ} / \mathrm{Nm}$ of polychlorinated dibenzodioxins, which was 10 times lower than the European standards of the time (Kopeykina, 2019).

However, long-term observation and regular sampling revealed a hazardously large concentration of polychlorinated dibenzodioxins in fume gases. In particular, the volume of emissions exceeded the limit for the plant 17 times in 2015 and equalled $0.17 \mathrm{nh}$ TEQ/Nm, being $0.07 n g$ TEQ/Nm higher than the limits set by the EU for plants using various technologies.

Researchers examined pastures and chicken eggs from farms located near the plant and discovered that in 2014 and 2015 the grass consumed by cows had contained almost twice as much polychlorinated dibenzodioxins as permitted by the standards $-1.2 \mathrm{ng}$ TEQ/Nm against $0.45 \mathrm{ng} \mathrm{TEQ} / \mathrm{Nm}$. Overall, the grass and eggs were on average 3 times more poisonous than grass and eggs from pastures and farms located further away from the plant. The conclusion of the study said emissions from the plant were the reason.

For a long time, nature was able to dispose of waste itself, but the advancement of human technology has played a vital part by bringing into the world new materials, the recycling of decomposition of which can go on for many hundreds of years if not facilitated. Nature cannot endure such an anthropogenic burden since the amounts of waste produced by the world population are enormous. 


\section{Conclusion}

As is show by the paper, the best ways to harness energy at nuclear and gas-fired power plants since all other potential sources of energy bear too many hazards and produce too many dangerous by-products. Moreover, natural gas can also be used as a motor fuel which eliminates the adverse effects of BaP presence in the air caused (directly or indirectly) by the use of other motor fuels.

\section{References}

COP24 Special Report on Health and Climate Change, World Health Organization, 2018. Retrieved from https://apps.who.int/iris/bitstream/handle/10665/276405/9789241514972-eng.pdf

Gao D., Wang C., Xi Z., Zhou Y., Wang Y., and Zuo Z., 2017. Early-Life Benzo[a]Pyrene Exposure Causes Neurodegenerative Syndromes in Adult Zebrafish (Daniorerio) and the Mechanism Involved. Toxicological Sciences, 157(1), 74-84.

Governmental Report on State and Protection of the Environment prepared by the Ministry of Natural Resources and Environment of the Russian Federation, 2017. Retrieved from: http://www.mnr.gov.ru/docs/o_sostoyanii_i_ob_okhrane_okruzhayushchey_sredy_rossiyskoy_f ederatsii/gosudarstvennyy_doklad_o_sostoyanii_i_ob_okhrane_okruzhayushchey_sredy_rossiy skoy_federatsii_v_2017_/

Gupta P.D., Muthukumar A. Minor to Chronic Eye Disorders Due to Environmental Pollution: A Review, 2018. Retrieved from https://www.longdom.org/open-access/minor-to-chronic-eye-disordersdue-to-environmental-pollution-a-review.pdf

Polycyclic aromatic hydrocarbons (Benzo[a]pyrene) Toxicological Overview, 2018. Retrieved from https://assets.publishing.service.gov.uk/government/uploads/system/uploads/attachment_data/fi le/737017/PAH_TO_PHE_240818.pdf

Rozanova E. et al. Environmental \& occupational non- traumatic effects on the eyes. Arh Hig Rada Toksikol 2009;60:205-215

Satyajit Patra, Araromi Adewale Andrew. Human, Social, and Environmental Impacts of Human Genetic Engineering / Journal of Biomedical Sciences, 2015

M. Wen, D. Gu. "Air Pollution Shortens Life Expectancy and Health Expectancy for Older Adults: The Case of China" The journals of gerontology. Series A, Biological sciences and medical sciences, 67 (11), 1219-29, 2012.

P. James, K. Ito, J. J. Buonocore, J. I. Levy, M. C. Arcaya. "A Health Impact Assessment of Proposed Public Transit Service Cuts and Fare Increases in Boston, Massachusetts", International Journal of Environmental Research and Public Health, 11. 2014.

S. C. van der Zee, P. H. Fischer, G. Hoek. "Air pollution in perspective: Health risks of air pollution expressed in equivalent numbers of passively smoked cigarettes", Environmental Research, 148, 475-83, 2016.

D.A. Leon. "Recessions and mortality: subtle but informative effects" The Lancet, 388(10060), 2016, 2572-2573

Viktoria Kopeykina. Western Scientists: the furnace turns waste into poison. Tsargrad. Retrieved from https://tsargrad.tv/articles/zapadnye-uchenye-musor-v-pechi-prevrashhaetsja-v-jad_195812 